\title{
Texto ou pretexto
}

\section{J. Guinsburg}

surto do chamado "teatro do diretor" nos últimos anos valorizou sobremaneira a invenção cênica como tal e a sua qualificação estética, que, se de uma parte apresentou, a partir do século XIX e principalmente com a definição do estatuto artístico do encenador, uma crescente objetivação e visibilidade crítica e pública, de outra parte, só mais recentemente configurou-se como uma tendência marcante do teatro contemporâneo.

Como toda corrente que adquire direito de cidadania na arte, esta também se distingue por uma presença específica de realizações singulares e representativas de seu modo de ser, cujo arrolamento e exame não cabe empreender aqui, já por sua riqueza e sua amplitude, as quais exigiriam de uma análise mais cuidadosa um longo acompanhamento histórico e exame crítico. Entretanto, ainda como toda corrente desta natureza, este tipo de criação dramática encerra, dentre numerosas e felizes soluçôes, alguns problemas que colocam em xeque não só a concepção tradicional de dramaturgia, como o próprio texto no teatro.

Não há a menor dúvida de que no teatro tudo é válido, desde que a resultante dos esforços criadores ofereça ao seu destinatário, a platéia, qualquer que seja ela, uma obra convincente, não por qualquer "fidelidade" literária ou respeito por cânones previamente estabelecidos, mas por suas virtudes cênicas, pela poesia de imagem e palavra em maior ou menor proporção uma em relação à outra e pela força trágica, cômica ou tragicômica da exposição dramática.

Isto posto, compreende-se que não há por que impugnar, em princípio, o uso que o inventor teatral possa fazer do legado dramatúrgico consagrado com o direito de permanência clássica, ou de quaisquer outros escritos modernos ou antigos, provenientes ou não da literatura dramática propriamente dita. Os acervos da épica e da lírica, por exemplo, no plano da norma culta ou popular, são provedores tão legítimos quanto as obras assinadas pelos mais reconhecidos gênios da locução dramatúrgica e da imaginação encenante. Se Mnouchkine fez do relato histórico da Revolução Francesa, se Peter Brook fez do relato lendário do Mahabarata védico e se Antunes Filho fez do relato mítico do Gilgamesh babilônico o que cada um deles fez, produzindo alguns dos maiores e mais marcantes espetáculos de nosso tempo, é evidente que só se poderia pôr em questão a procedência formal de seus materiais por um espírito tacanho de dogmatismo estético.

De modo que, nas linhas que nortearam a presente reflexão, não há lugar para as conhecidas acusações com respeito à indiscriminação

J. Guinsburg é professor emérito do Departamento de Artes Cênicas da ECA-USP. 
com que os diretores buscam atualmente os componentes textuais de suas obras no palco. Fala-se em falta de critérios, em manipulação arbitrária e em destruição do teatro de repertório tout court. E como resposta propugna-se até a volta pura e simples à fidelidade estrita à letra. Uma outra proposta é a do livre uso das peças mais renomadas e de eficácia cênica comprovada. Esta, aliás, é uma das que têm recebido a melhor acolhida, mesmo porque não há homem de teatro, ator, encenador ou dramaturgista, que não queira pôr-se à prova em um confronto direto com um Shakespeare, um Calderon, um Sófocles ou um Tchekhov. Tal desafio faz parte da própria natureza da arte do comediante e de sua explicitação cênica nas grandes máscaras do drama e da comédia.

Mas é justamente aí que aparece um problema difícil de resolver e muitas vezes um impasse. Até onde a criatividade e a teatralidade podem dispor a seu bel-prazer, segundo ditames intrínsecos exclusivamente ao seu próprio estro, das estruturas e valores de composições e de personagens concebidos, construídos e firmados de um modo definido, se não definitivo? Quando se retira uma peripécia de menor importância ou uma figura secundária, que podem até ter uma bela expressão no escrito canônico, a economia geral da peça pode não ser afetada. Ou então, quando se altera o ritmo de algumas ações, ou se modificam determinadas relaçõos de força, ou ainda a interpretação de certas características sem interferir na proposta básica, as variações e os recortes podem até ser benéficos para os efeitos dramáticos visados. Mas, como julgar uma intervenção que, por exemplo e para fins de argumentação, transmute o caráter trágico do Rei Lear em uma feição puramente cômica ou desbragadamente melodramática? É claro que estes traços estão também contidos na peça shakespeariana, mas aí eles estão dominados pelo vetor trágico e não são dominantes. Um outro caso que é possível trazer à baila é o do repertório tchekhoviano. Uma tendência que vem caracterizando as suas montagens mais recentes em nossos palcos é o de expungi-lo de sua marcação psicológica, não tanto no plano das máscaras individuais, quanto no da "atmosfera" que as envolve. Ora, tal procedimento oferece o benefício de dinamizar a ação e mesmo de precipitá-la por sua incorporação física imediata nos caracteres, porém atinge na medula o tempo existencial que o autor suscitou a fim de consumir-lhes o sentido de suas vidas.

Vê-se que, por deliberação ou como subproduto, a natureza da dramaticidade articulada na obra e a própria organicidade de sua construção teatral ficariam por este viés, nos autores acima citados, gravemente atingidas e mesmo aniquiladas. Isto significa que o uso do texto, e sobretudo de um texto carregado pelo consenso de validade estética em função de um determinado perfil, não pode servir como um mero pretexto para a invenção cênica, mesmo que bem sucedida. Ou melhor, nesta hipótese, o inventor do novo script deve assumir plenamente a sua autoria e responsabilidade, e não deferi-la, com um simples rótulo de "adaptação", ao original e ao seu criador. Meierhold percebeu muito bem esse limite ético e artístico quando em sua hoje lendária encenação de $O$ Inspetor $G e$ ral, de Gógol, atribuiu a si próprio o conjunto da versão que estava pondo no palco e no qual realizou um extraordinário trabalho de reformulação intrínseca da peça, segundo propósitos específicos da sua mise en scène voltada para o grotesco, com materiais do próprio novelista de Almas Mortas. 